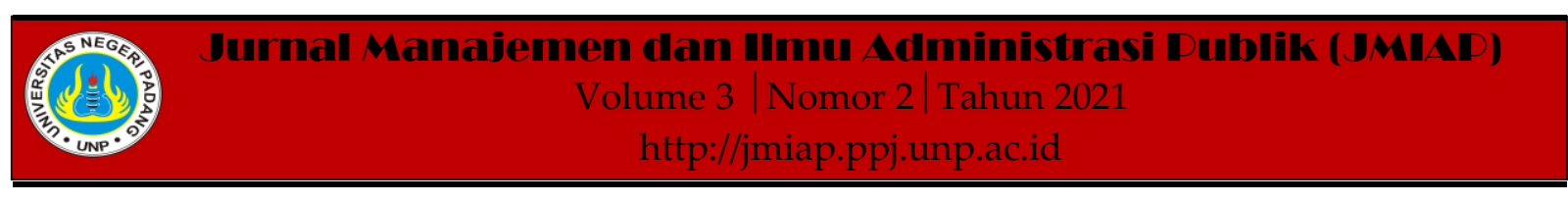

\title{
KOORDINASI PEMERINTAHAN DALAM PENANGGULANGAN PELADANGAN GANJA PADA KABUPATEN GAYO LUES
}

\author{
Desta Ariga $^{1(a)}$, Jumiati $^{2(b)}$ \\ ${ }^{1}$ Jurusan Ilmu Administrasi Negara, Universitas Negeri Padang \\ ${ }^{2}$ Jurusan Ilmu Administrasi Negara, Universitas Negeri Padang \\ a)destaariga1997@gmail.com, ${ }^{b)}$ jumiati@fis.unp.ac.id
}

\begin{abstract}
This study aims to determine the coordination carried out by the Gayo Lues Regency government in overcoming cannabis cultivation, and also how the obstacles that occur when implementing coordination in tackling cannabis cultivation both between one agency and another as well as between agencies and the community and to find out the efforts made by the government. (BNNK, Polri, TNI) in tackling cannabis cultivation in Gayo Lues Regency. This research uses qualitative research using descriptive method which is carried out by means of purposive sampling. Data collection techniques were carried out by interviews and documentation studies, with informants of several employees at the Gayo Lues Regency National Narcotics Agency, Gayo Lues District Police, Gayo Lues District Military Command, community leaders and communities who live in areas prone to cannabis cultivation. The results of this research indicate that the collaboration formed by the BNN Gayo Lues Regency, the Police and the Kodim 0113 Gayo Lues has been carried out as much as possible but efforts are still needed to change the mindset of the community. The coordination carried out by the government is for preventive activities carried out by the District National Narcotics Agency (BNNK) Gayo Lues, while the Police and Kodim 0113 Gayo Lues are more concerned with law enforcement. The obstacles experienced by the government in overcoming cannabis cultivation are divided into 2 (two), namely internal constraints and external constraints. Internal constraints such as the lack of personnel, the absence of technology in tackling cannabis cultivation and the distance of the cannabis fields, while the external constraints are more to the people themselves. The efforts made by each agency are different, such as the National Narcotics Agency of Gayo Lues Regency which emphasizes work programs, while for the Police and Kodim 0113 Gayo Lues strives by requesting an increase in the number of personnel and the procurement of technology to combat marijuana.
\end{abstract}

Keywords : Coordination, Governance, Handling, Cannabis Farming

Corresponding author. Email. destaariga1997@gmail.com

How to cite this article. Ariga, D \& Jumiati (2021). Koordinasi Pemerintahan dalam Penanggulangan Peladangan Ganja pada Kabupaten Gayo Lues. Jurnal Manajemen dan Ilmu Administrasi Publik (JMIAP) Jurusan Ilmu Administrasi Negara Fakultas Ilmu Sosial Universitas Negeri Padang, Volume 3 (2), Hal. 144-152.

http://jmiap.ppj.unp.ac.id

Copyright@2021. Published by Labor Jurusan Ilmu Administrasi Negara FIS UNP, Padang 


\section{PENDAHULUAN}

Ganja merupakan Tumbuhan yang dari dulu kala telah dikenal oleh manusia dengan banyaknya manfaat serta sisi positifnya, dapat dilihat mulai dari daun ganja, ranting ganja, akar ganja semua bisa dimanfaatkan oleh manusia. Ganja juga memiliki manfaat dalam bidang medis dalam pengobatan, diantaranya untuk mengobati penyakit HIV/AIDS, imsonia, kanker, dan lain sebagainya. Namun karena ganja juga dikenal sebagai sumber narkotika dan kegunaan ini lebih bernilai ekonomi bagi kalangan masyarakat, orang lebih banyak menanamnya untuk hal ini.

Ganja memiliki banyak manfaat dalam bidang medis dan pengobatan akan tetapi dari sisi negatifnya juga banyak masyarakat yang menyalahgunakanya dengan cara melakukan peladangan ganja di daerahdaerah tertentu seperti Penemuan ladang ganja pada Kabupaten Gayo Lues baru-baru ini tergolong sangat mengejutkan, karena jumlah ladang ganja yang ditemui sangat fantastis. Pada tanggal 4 Maret 2020 BNN Kabupaten Gayo Lues, TNI dan Polri berhasil menemukan ladang ganja seluas 25 hektar, serta di tahun sebelumnya juga ditemukan ladang ganja seperti di tahun 2015 ditemukan ladang ganja seluas 13,5 hektare atau sekitar 32 ribu batang ganja di kawasan pegunungan Jamur Atu Desa Agusen dan 22 hektare pada kawasan Gunung Leuser, di tahun 2016 ditemukan tiga ladang ganja yaitu tanggal 09 bulan februari 2016 ditemukan ladang ganja seluas 8 hektare dan pada tanggal 21 Agustus 2016 ditemukan kembali ladang ganja seluas 15 hektare yang berlokasi sama yaitu di Desa Agusen serta 6 hektare yang berlokasi di Akang Siwah Kecamatan Blangpegayon. Di tahun 2018 ditemukan 2 ladang ganja yaitu seluas 3 hektare dan 6 hektare yang berlokasi di pegunungan Aih Kering Pining serta di tahun 2019 ditemukan kembali ladang ganja seluas 4 hektare yang berlokasi di Agusen. Jadi, jika dijumlahkan dalam kurun waktu 5 tahun terakhir ini terjadi 5 kali kasus peladangan ganja dengan total keseluruhan seluas 61,5 Hektare.

Melihat maraknya peladangan ganja pada Kabupaten Gayo Lues ini tentunya tidak lepas dari banyaknya produksi atau penanaman ganja di kalangan masyarakat, Pemerintahan memiliki suatu lembaga khusus yang menanggulangi peladangan ganja yaitu Badan Narkotika Nasional Kabupaten (BNNK) Gayo Lues, serta nantinya akan dibantu oleh instansi aparat yaitu Polres dan Kodim 0113 Kabupaten Gayo Lues.

Dalam penanggulangan peladangan ganja perlu adanya koordinasi yang baik pada pemerintahan Kabupaten Gayo Lues. Kurangnya koordinasi antara lembaga yang menanggulangi peladangan ganja ini dapat berdampak buruk terhadap kesejahteraan masyarkat seperti masalah peladangan ganja yang dari tahun ke tahun selalu mengejutkan masyarakat dengan jumlah ladang ganja yang ditemukan, Dalam hal mengatasi peladangan ganja pemerintahan daerah juga dibantu oleh pemerintah kampung. Pemerintahan Kampung mempunyai tugas pembantuan dari Pemerintah Provinsi dan Pemerintah Kabupaten kepada kampung atau desa.

Perlunya pemerintahan daerah dalam menanggulangi peladangan ganja serta keresahan yang dialami masyarakat kabupaten Gayo Lues terhadap peladangan ganja ini, maka permasalahan peladangan ganja pada Kabupaten Gayo Lues ini berhubungan dengan teori tentang koordinasi pemerintahan dalam menanggulangi peladangan ganja yang menjelaskan tentang koordinasi, hambatan serta upaya apa saja yang dilakukan Pemerintahan (BNNK, Polri dan TNI) dalam penanggulangan peladangan ganja pada Kabupaten Gayo Lues diantaranya Badan Narkotika Nasional (BNN) Kabupaten Gayo Lues, Polres Kabupaten Gayo Lues.

\section{TINJAUAN PUSTAKA}

Menurut Afendi, Masjaya \& Burhanudin (2019:547) koordinasi itu adalah suatu 
usaha kerja sama antara badan, instansi, atau unit melalui proses penyepakatan bersama secara mengikat berbagai kegiatan atau unsur yang berbeda-beda sedemikian rupa untuk mengarahkan pelaksanaan tugas-tugas tertentu agar menghasilkan suatu tindakan yang seragam dan harmonis pada sasaran yang telah ditentukan.

Berdasarkan pernyataan di atas maka dapat disimpulkan bahwasanya koordinasi itu adalah suatu usaha yang dilakukan secara bersama untuk mencapai suatu tujuan yang telah ditentukan dan dapat berjalan dengan yang diinginkan.

\section{Konsep Pemerintahan}

Dalam jurnal Herry Suharyadi \& Mohamad Aji Insani (2016:243) Pada dasarnya pemerintah adalah sekelompok orang yang diberi kekuasaan legal oleh masyarakat setempat untuk melaksanakan pengaturan atas interaksi yang terjadi dalam pergaulan masyarakat untuk memenuhi kebutuhan dan keperluan hidup sehari-hari, sehingga interaksi tersebut dapat berjalan secara harmonis."(Salam, 2007: 34).

Sedangkan menurut pandangan Ndraha (1997;6-7) pemerintahan adalah gejala sosial, artinya terjadi di dalam hubungan antar anggota masyarakat, baik individu dengan individu, kelompok dengan kelompok, maupun antar individu dengan kelompok.

Berdasarkan pernyataan diatas maka dapat disimpulkan pemerintahan itu adalah penyelenggaraan urusan pemerintahan yang dilaksanakan oleh pemerintah untuk mencapai tujuan yang diinginkan melalui gejala sosial diantaranya hubungan yang terjadi pada anggota masyarakat.

\section{Konsep Penanggulangan}

Menurut Fadhlullah (2017:108-111) Dalam hal penanaman ganja ini, Sayyid Sabiq mengatakan bahwa penanaman ganja ini tercantum dalam fatwa Mufti Negara Mesir Syeikh Abdul Majid Salim, fatwa tersebut menjawab pertanyaan mengenai hukum bertani ganja untuk maksud memperjual belikannya atau untuk membuat benda-benda yang memabukkan guna dipakai atau diperdagangkan. Dalam fatwa tersebut kemudian Syeikh Abdul Majid Salim menjawab bahwa bertani ganja dengan maksud akan membuat benda memabukkan untuk dipakai sendiri, dipakai orang lain atau diperjualbelikan adalah haram hukumnya, alasanya sebagai berikut:

1) Keterangan yang terdapat dalam hadist yang diriwayatkan oleh Abu Daud dan lain-lain dari Ibnu Abbas, dari Rasulullah yang mengatakan "Sesungguhnya orang yang memerah anggur pada hari-hari memetiknya kemudian menjualnya kepada orang yang akan menjadikannya khamar, maka sesungguhnya dia telah menceburkan diri ke neraka". Hadist ini menunjukkan haramnya menanam ganja dan candu untuk maksud-maksud seperti diatas;

2) Bahwa perbuatan seperti itu berarti mendukung kemaksiatan, yaitu menggunakan benda-benda yang memabukkan atau memperjual belikannya. Maka membantu perbuatan maksiat adalah perbuatan maksiat;

3) Bahwa menanam tanaman yang memabukkan untuk maksud tersebut tadi berarti relanya si penanam terhadap penggunaan benda-benda tersebut atau diperjual belikannya. Sikap rela terhadap kemaksiatan adalah juga maksiat. Sebab tidak setujunya seseorang, yang berarti hatinya benci kepada sesuatu kemungkaran, hal ini merupakan kewajiban yang dibebankan kepada setiap muslim dalam setiap saat. Dengan demikian jelaslah bahwasanya setiap orang Islam yang beriman diharuskan untuk mencegah terjadinya kemungkaran dan kejahatan seperti penanaman ganja yang terjadi di sekitarnya atau yang ada dalam masyarakat. Pencegahan tersebut kemudian diharapkan akan menjaga ketentraman di kalangan masyarakat dan kemaslahatan yang lebih besar dari pada keuntungan yang didapatkan oleh para pembuat kemungkaran. 


\section{Konsep Peladangan Ganja}

\section{1) Peladangan}

Menurut Kamus Besar Bahasa Indonesia peladang adalah orang yang mengusahakan ladang; sedangkan peladangan adalah petani ladang bertani yang hidup dari bercocok tanam dengan cara berpindah-pindah dari satu ladang ke ladang yang baru sebagai mata pencarian hidupnya, sistem bercocok tanam berpindah-pindah dari satu bidang tanah (ladang) ke bidang tanah yang lain, biasanya dibuka dengan menebang dan membakar sebagian hutan.

Sedangkan dalam situs wikipedia dikatakan bahwa peladangan itu adalah sebuah sistem bercocok tanam berpindahpindah dari satu bidang tanah atau ladang ke bidang tanah yang lain, biasanya dibuka dengan menebang dan membakar sebagian hutan untuk membuat ladang. Ini adalah teknik pertanian subsisten yang biasanya menggunakan sedikit teknologi atau alat lainnya. Hal ini biasanya menjadi bagian dari pertanian ladang berpindah.

Berdasarkan pernyataan diatas maka dapat disimpulkan bahwasanya peladangan itu adalah suatu sistem bertani yang dilakukan dengan cara berpindah-pindah dan biasanya dibuka dengan cara membakar atau dengan cara menebang.

\section{2) Ganja}

Tumbuhan ganja telah dikenal manusia sejak lama karena banyak manfaatnya dan digunakan sebagai bahan pembuat plastik karena serat yang dihasilkannya kuat, biji ganja juga digunakan sebagai sumber minyak industri dan minyak esensial, namun karena ganja juga dikenal sebagai sumber narkotika dan kegunaan ini lebih bernilai ekonomi, orang lebih banyak menanamnya untuk hal ini. Ganja sangat terkenal dan hampir tidak ada masyarakat Aceh yang tidak pernah mendengar tentang ganja, ganja juga sering disebut dengan istilah bakoeng, cimeng dan gelek. Terkenalnya ganja bukan karena manfaat ilmu pengetahuan atau termasuk ke dalam rempah-rempah, melainkan karena adanya zat THC (Tetra Hidro Cannabinol) di dalamnya yang dapat membuat pemakainya merasakan beberapa efek seperti euforia (rasa senang yang berkepanjangan tanpa sebab) serta timbulnya ketergantungan. (Fadhlullah,2017:90).

Dari penjelasan kedua konsep diatas yaitu mengenai peladangan dan ganja maka dapat disimpulkan bahwasanya peladangan ganja itu adalah suatu sistem bercocok tanam yang dilakukan seseorang baik dengan cara menebang, membakar dan lain sebagainya untuk dijadikan sebagai ladang yang nantinya akan ditanami oleh tanaman ganja.

\section{METODE PENELITIAN}

Metode penelitian ini menggunakan sifat deskriptif dengan pendeketan kualitatif, yaitu penelitian ini mencoba menggungkapkan dan menggambarkan semua kejadian yang terjadi apa adanya dan semua fenomena-fenomena yang terjadi dan dibuat dalam bentuk keteranganketerangan. penelitian ini dilakukan di Dinas Badan Narkotika Nasional Kabupaten Gayo Lues, Polres Kabupaten Gayo Lues, dan Kodim 0113 Kabupaten Gayo Lues.Data dikumpulkan melalui wawancara dan studi dokumentasi.Uji keabsahan data dilakukan dengan teknik triangulasi sumber. Teknik pengolahan data dengan reduksi, penyajian data dan penarikan kesimpulan.

\section{HASIL DAN PEMBAHASAN}

Koordinasi Pemerintahan dalam
Menanggulangi Peladangan Ganja pada
Kabupaten Gayo Lues
Melihat dari berbagai hasil wawancara penulis dengan para informan peneletian, didapatlah informasi mengenai koordinasi pemerintahan dalam menanggulangi peladangan ganja pada Kabupaten Gayo Lues. Berbicara mengenai koordinasi pemerintahan dalam menanggulangi peladangan ganja pada Kabupaten Gayo Lues dengan berlandaskan beberapa hasil penelitian diketahui bahwasanya koordinasi yang dilakukan sudah berjalan dengan 
efektif dapat dilihat dari kerjasama yang dilakukan antara instansi yang satu dengan yang lainya bahkan pemerintah kampung juga ikut serta dalam menanggulangi peladangan ganja ini. Masyarakat biasanya memberikan informasi kepada salahsatu instansi dan dilakukan pengintain oleh Polri jika terdapat ladang ganja maka dihubungilah pihak BNN Kaupaten Gayo Lues dan TNI, setelah itu barulah dilakukan razia dan pemusnahan ladang ganja. Setiap instansi memiliki peran masing-masing dalam penanggulangan peladangan ganja ini misalnya instansi BNN Kabupaten Gayo Lues yang berperan dalam pencegahan melalui program sosialisasi sedangkan untuk pemberantasan melibatkan pihak TNI dan Polri.

Koordinasi pemerintahan dalam menanggulangi peladangan ganja ini pihak BNN Kabupaten Gayo Lues merupakan fasilitator yang menghubungkan antara instansi satu dengan lainya serta juga tidak terlepas dari peran pemerintah kampung yang memberikan dukungan baik dalam hal pemusnahan ladang ganja maupun dalam kegiatan sosialisasi yang dilakukan oleh pihak BNN Kabupaten Gayo Lues beserta aparat hukum. Pemerintahan melalui BNN Kabupaten Gayo Lues juga memiliki program bersama Dinas Lingkungan Hidup dimana bekas ladang-ladang ganja tersebut dijadikan sebagai perhutanan sosial. Jadi, masyarakat bisa menanami kembali bekasbekas ladang ganja ini dengan tanaman komoditi seperti kopi, jagung, dan lain-lain.

Tujuan dalam koordinasi ini juga dapat dilihat pada bab sebelumnya dimana tujuan yang hendak dicapai agar masyarakat yang melakukan penanaman ladang ganja dapat diminimalisir dan dimusnahkan secepat mungkin oleh pihak instansi pemerintahan.

Jika milihat dari kajian teori tujuan koordinasi dari buku yang disusun oleh Asdep Jaminan Sosial \& LPM Universitas Pasundan (2015:19-20) yang berjudul "Koordinasi Pengelolaan Program Jaminan Sosial" maka belum terjadinya kesepakatan antara instansi yang satu dengan yang lainya akan tetapi tujuan yang dilakukan oleh pihak instansi pemerintahan memiliki maksud dan tujuan yang sama yaitu agar kasus peladangan ganja di Kabupaten Gayo Lues dapat dihilangkan secepat mungkin baik dengan cara melakukan sosialisasi dan cara-cara yang lain.

Jika mengacu kepada indikator koordinasi oleh Handayaningrat (1989:80), yaitu komunikasi, kesadaran pentingnya koordinasi, kompetensi partisipan, kesepakatan, komitmen dan insentif koordinasi serta kontinuitas perencanaan. Terdapatlah bukti dokumentasi beberapa bentuk realisasi upaya penanangulangan peladangan ganja,yang dilakukan oleh pemerintahan Kabupaten Gayo Lues serta dapat dilihat pada tabel program kerja yang dipaparkan diatas.

Kesatupaduan antara instansi yang melakukan upaya untuk mengurangi kultivasi peladangan ganja dapat dilihat pada bab sebelumnya, dimana pemerintahan telah melakukan upayanya untuk selalu mengurangi dan memberantas kultivasi ganja melui program yang diadakan oleh BNN Kabupaten Gayo Lues, pemberantasan yang dilakukan Polres Kabupaten Gayo Lues dengan target setiap tahunya serta pengawasan yang juga dilakukan oleh pihak Kodimm 0113 Gayo Lues.

Jika melihat dari teori sifat koordinasi Hasibuan (2007:87) dalam Mali, Uskono \& Taus yaitu koordinasi bersifat dinamis bukan statis, koordinasi menekankan pandangan menyeluruh oleh seorang koordinator dalam rangka mencapai sasaran, koordinasi meninjau suatu pekerjaan secara keseluruhan maka instansi pemerintahan telah melaksanakannya secara optimal dilihat dari setiap program BNN Kabupaten Gayo Lues, Polres dan TNI yang dilakukan bersama untuk menanggulangi kasus peladangan ganja ini. Hanya saja untuk koordinator dalam menanggulangi peladangan ganja dilakukan pada setiap instansi untuk sosialisasi lebih berperan BNN Kabupaten Gayo Lues sedangkan untuk pemusnahan ladang ganja tergantung pada instansi mana yang 
pertama menerima informasi oleh masyarakat baik BNN Kabupaten Gayo Lues maupun TNI dan Polri.

Penanggulangan yang dilakukan bersama oleh instansi yang terkait dalam menanggulangi kasus peladangan ganja ini seperti pemusnahan ladang ganja yang dilakukan bersama-sama tanpa adanya wewenang dan lembaga yang lebih tinngi. Maka dapat ditarik kesimpulah bentuk koordinasi yang dilakukan oleh BNN Kabupaten Gayo Lues, TNI dan Polri berbentuk Horizontal (Sederajat).

Bekerja sama merupakan suatu point yang diutamakn dalam koordinasi dapat dilihat pada bab sebelumnya dimana setiap instansi pemerintahan memiliki wewenang masing-masing dan disatupadukan sebagai kerjasama yang solid seperti BNN kabupaten Gayo Lues yang lebih kepada pencegahan dalam penannggulangan peladangan ganja sedangkan TNI dan Polri yang bertugas sebagai penindakan atau penegakan hukum. Setiap instansi berupaya semaksimal mungkin untuk menanggulangi kasus peladangan ganja dimulai dari BNN Kabupaten Gayo Lues yang memperbanyak program sosialisasinya ditambah pihak aparat TNI dan Polri yang senantiasa melakukan pengawasan dan pemusnahan ladang ganja.

Melihat dari syarat-syarat koordinasi Hasibuan (2007:88) yaitu Sense of cooperation (perasaan untuk bekerja sama), Rivalry, Team spirit dan Esprit de corps. Maka instansi pemerintahan Kabupaten Gayo Lues telah melaksanakanya secara efektif baik dalam hal kerjasama yang dilakukan berupa program kerja, pengawasan dan target pemusnahan ladang ganja pada Kabupaten Gayo Lues.

\section{Kendala dalam Proses Koordinasi Pemerintahan untuk Menanggulangi Peladangan Ganja pada Kabupaten Gayo Lues}

Masalah kerjasama aparatur pemerintahan dan pertaliannya antara satu dengan yang lainnya merupakan masalah koordinasi pemerintahan yang begitu penting dan sangat diprioritaskan artinya masalah ini disebabkan oleh kebutuhan akan adanya koordinasi itu sebagai akibat dari adanya kekuatan-kekuatan yang hidup dalam lingkungan lembaga-lembaga pemerintahan seperti yang ada pada lembaga BNN Kabupaten Gayo Lues, Polres dan Kodim 0113 Kabupaten Gayo Lues serta berbagai macam ragamnya yang seringkali terlihat bahwa dalam penyelenggaraan tugasnya berlawanan antara satu dengan yang lainya.

Masalah koordinasi pemerintahan ini juga terdapat pada tingkat pemerintahan di pusat dan juga di daerah, baik di tingkat provinsi maupun ditingkat kabupaten/kota serta juga ditingkat kecamatan atau sampai tingkat desa sekalipun. Dalam melaksanakan penyelenggaraan kegiatan pemerintahan daerah, permasalahan koordinasi pemerintahandan sangat berpengaruh terhadap terlaksananya koordinasi adalah kesiapan SDM (sumber daya manusia) aparatur pemerintah daerah yang ada dalam melaksanakan kewenangan yang diemban. Profesionalitas aparatur pemerintah merupakan salah satu hal terpenting agar memiliki kemampuan pelaksanaan tugas, adanya komitmen terhadap kualitas kerja, dedikasi terhadap kepentingan masyarakat sebagai pihak yang dilayani oleh pemerintah daerah tersebut.

Kendala dalam proses koordinasi pemerintahan untuk menanggulangi peladangan ganja pada Kabupaten Gayo Lues yang telah dibahas pada bab sebelumnya juga penulis paparkan beberapa hal, seperti kutipan dari Ibu Aramini yang menyatakan bahwa hambatan terjadi karena susahnya mengubah minset masyarakat serta menurut pandangan bapak Muhammad selaku Gecik Desa Agusen yang mengatakan bahwa butuhnya perhatian khusus pemerintahan terhadap perekonomian masyarakat dan juga pendapat dari Bapak Mahadi. S dan Bapak Iyal MT yang menyatakan hambatanya dalam lokasi geografis lahan ganja yang 
sangat sulit, ini merupakan faktor penghambat yang perlu diperhatikan agar kasus peladangan ganja pada Kabupaten Gayo Lues dapat dikurangi serta dimusnahkan.

\section{Kendala Internal dan Eksternal yang Menjadi Hambatan pada Koordinasi Pemerintahan dalam Penanggulangan Peladangan Ganja pada Kabupaten Gayo Lues}

Berdasarkan hasil penelitian dapat diketahui bahwa faktor yang menghambat koordinasi Pemerintahan Dalam Penanggulangan Peladangan Ganja Pada Kabupaten Gayo Lues adalah karena masih rendahnya tingkat perekonomian masyarakat yang membuat masyarakat masih berani serta nekat untuk menanami peladangan ganja tersebut. Selain itu faktorfaktor yang juga menjadi hambatan pada koordinasi pemerintahan dalam penanggulangan peladangan ganja pada Kabupaten Gayo Lues, penulis telah melakukan hasil wawancara dengan ketiga instansi dalam penelitian ini. Pertama, penulis menjelaskan dari beberapa hasil wawancara yang didapatkan mulai dari wawancara yang didapatkan dari Badan Narkotika Nasional Kabupaten Gayo Lues, Polres Kabupaten Gayo Lues, dan Kodim 0113 Kabupaten Gayo Lues.

Dari hasil wawancara yang penulis dapatkan di lapangan bahwa ada beberapa poin yang menjadi faktor penghambat koordinasi pemerintahan dalam penanggulangan peladangan ganja pada Kabupaten Gayo Lues, yaitu : faktor internal dan faktor eksternal:

1. Kendala internal

a) Tidak adanya teknologi yang dimiliki Kodim 0113 Kabupaten Gayo Lues dalam proses pencarian ladang ganja seperti drone dan helikopter;

b) Keterbatasan jumlah personil yang dimiliki oleh Polres Kabupaten Gayo Lues pada satresnarkoba yang hanya berjumlah 16 personil; c) Tidak adanya satelit sehingga pihak polres Kabupaten Gayo Lues susah dalam berkomunikasi.

2. Kendala eksternal

a) Sulitnya Badan Narkotika Nasional Kabupaten (BNNK) Gayo Lues dalam mengubah pola pikir (minset) masyarakat yang masih awan, dimana masih saja melakukan peladangan ganja;

b) Letak ladang ganja yang cukup jurang serta harus mempersiapkan bekal untuk penginapan karena jarak tempuh ke ladang yang memakan waktu cukup lama.

Jika mengacu kepada teori Gow dan Mors dalam pasolong (2010:59) maka Kendala dapat didefinisikan sebagai segala sesuatu yang menghambat suatu sistem untuk mencapai tujuan yang telah ditetapkan sebelumnya.

Menurut teori diatas maka kendala yang terjadi pada koordinasi pemerintahan dalam menanggulangi peladangan ganja pada Kabupaten Gayo Lues merupakan point terpenting yang harus diselesaikan secepat mungkin agar tujuan yang hendak dicapai dapat berjalan sesuai dengan yang diharapkan.

Kendala koordinasi yang terjadi pada pemerintahan Kabupaten Gayo Lues dalam menanggulangi peladangan ganja juga bisa dibahas dengan faktor-faktor yang mempengaruhi koordinasi yaitu kesatuan tindakan, komunikasi, pembagian kerja, dan disiplin. Pada pembahasan sebelumnya juga dikatakan bahwa semua lembaga mempunyai kesatuan tindakan dalam menanggulangi peladangan ganja dan komunikasi yang sangat aktif antara pihak BNN Kabupaten Gayo Lues dengan TNI maupun Polri dapat dilihat dalam upaya pemerintahan Kabupaten Gayo Lues dalam menanggulangi dan memusnahkan ladang ganja. Pembagian kerja yang telah terstruktur, dimana BNN Kabupaten Gayo Lues lebih menitik beratkan pada Proses sosialisasi (Pencegahan) sedangkan TNI dan Polri sebagai lembaga yang melakukan penindakan hukum, disiplin pastinya 
diutamakan dapat dilihat dari target Polri setiap tahunya dalam menanggulangi peladangan ganja yaitu minimal 2 kali pemusnahan, TNI yang selalu menerima dan mengawasi masyarakat serta BNN Kabupaten Gayo Lues yang senantiasa melakukan program sosialisasi dan melakukan pemberdayaan kepada mantan petani ganja dan narapidana.

\section{Upaya yang Dilakukan dalam Koordinasi Pemerintahanan untuk Menaggulangi Kasus Peladangan Ganja pada Kabupaten Gayo Lues}

Upaya yang dilakukan oleh pemerintahan dalam menanggulangi peladangan ganja dapat terlihat bagi penulis dalam kumpulan informasi- informasi diatas salah satunya adalah pada saat ini pihak BNN Kabupaten Gayo Lues yang sedang menyusun suatu regulasi yang dinamakan dengan Tim Terpadu Kabupaten sebagai suatu program untuk menyususn stratregi dalam mencapai tujuan pada instansi BNN Kabupaten Gayo Lues. Sedangkan menurut bapak Mahadi. S bahwasanya perlunya dilakukan pengawasan terhadap masyarakat agar tidak lagi melakukan peladangan ganja, selanjunya menurut bapak Iyal MT upaya yang harus ditekankan dalam penanggulangan peladangan ganja ini adalah dengan meningkatkan program sosialisasi agar pola pikir masyarakat dapat berubah, berbeda dengan pandangan zulkifli yang menuturkan bahwa upaya yang harus diutamakan adalah dengan memberikan pemberdayaan yang terstruktur kepada masyarakat.

Dalam hasil wawancara di atas setiap informan memiliki pandangan yang berbeda-beda, ini menyatakan bahwasanya setiap instansi memiliki strateginya masingmasing dalam melakukan penanggulangan peladangan ganja serta perlunya pelaksanaan upaya yang efektif agar tercapainya tujuan koordinasi yang tepat sasaran.

Jika mengacu kepada Teori upaya Menurut Tim Penyusun Departemen
Pendidikan Nasional (2008:1787), dalam Novitasari upaya adalah usaha, akal atau ikhtiar untuk mencapai suatu maksud, memecahkan persoalan, mencari jalan keluar, dan sebagainya.

Melihat dari sudut pandang teori diatas maka dapat dikatakan bahwa upaya penanggulangan peladangan ganja yang perlu dilakukan adalah adanya komitmen bersama dalam melakukan pencegahan, pemberantasan agar peladangan ganja di Kabupaten Gayo Lues ini dapat dihilangkan.

\section{PENUTUP}

Berdasarkan permasalahan yang diteliti dan temuan penelitian dapat ditarik kesimpulan sebagai berikut:

1. Koordinasi Pemerintahan Dalam Menanggulangi Peladangan Ganja Pada Kabupaten Gayo Lues dapat dikatakan cukup efektif karena melihat program yang cukup terstruktur dan terarah yang dilakukan oleh pemerintahan yang dilaksanakan oleh Badan Narkotika Nasional (BNN) Kabupaten Gayo Lues, Polres Kabupaten Gayo Lues serta Kodim 0113 Kabupaten Gayo Lues. Akan tetapi, permasalahan yang terjadi dalam kasus peladangan ganja ini adalah berada pada pola pikir (minset) masyarakatnya yang masih awam serta nyaman dalam melakukan peladangan ganja.

2. Kendala internal dan eksternal pada koordinasi pemerintahan dalam menanggulangi kasus peladangan ganja di Kabupaten Gayo Lues ini diantaranya:

a. Kendala internal

1) Tidak adanya teknologi yang dimiliki Kodim 0113 Kabupaten Gayo Lues dalam proses pencarian ladang ganja seperti drone dan helikopter

2) Keterbatasan jumlah personil yang dimiliki oleh Polres Kabupaten Gayo Lues pada satresnarkoba yang hanya berjumlah 16 personil 
3) Tidak adanya satelit sehingga pihak polres Kabupaten Gayo Lues kesulitan dalam berkomunikasi

4) Letak ladang ganja yang cukup jurang serta harus mempersiapkan bekal untuk penginapan karena jarak tempuh ke ladang yang memakan waktu cukup lama (sarana dan prasarana)

b. Kendala eksternal

1) Sulitnya Badan Narkotika Nasional Kabupaten (BNNK) Gayo Lues dalam mengubah pola pikir (minset) masyarakat yang masih awan, dimana masih saja ingin melakukan peladangan ganja di Kabupaten Gayo Lues

2) Rendahnya perekonomian masyarakat merupakan salah satu alasan mengapa Masyarakat melakukan penanaman ganja yang secara hukum telah dilarang oleh Negara Kesatuan Republik Indonesia.

3. Upaya yang dilakukan setiap instansi berbeda-beda seperti Badan Narkotika Nasional Kabupaten Gayo Lues yang menekankan kepada program kerjanya sedangkan untuk Polres dan Kodim 0113 Gayo Lues mengupayakan dengan permintaan penambahan jumlah personel yang dirasa masih kurang yaitu sekitar 16 personel untuk Polres Kabupaten Gayo Lues dan pengadaan teknologi untuk penanggulangan peladangan ganja seperti helikopter, drone, satelit komunikasi dan lain sebagainya.

\section{DAFTAR KEPUSTAKAAN}

Afendi, S., Masjaya, \& Burhanudin. (2019). Koordinasi Pemerintahan Dalam Pengendalian Daerah Aliran Sungai ( DAS ). 7(2), 545-558.

Helviza, I., Mukmin, Z., \& Amirullah. (2016). Kendala-Kendala Badan
Narkotika Nasional (Bnn) Dalam Penanggulangan Penyalahgunaan Narkotika Di Kota Banda Aceh. Jurnal Ilmiah Mahasiswa Pendidikan Kewarganegaraan Unsyiah, 1(1), 128146.

Hasibuan, M. (2007). Manajemen Sumber Daya Manusia. Jakarta: Bumi Aksara.

Indah Devi Novita Sari. (2014). Upaya Guru Dalam Meningkatkan Keberanian Siswa Untuk Bertanya Pada Pembelajaran Pendidikan Kewarganegaraan. Implementation Science, 39(1), 1-15. Retrieved from http://dx.doi.org/10.1016/j.biochi.2015 .03.025\%0Ahttp://dx.doi.org/10.1038/ nature 10402\%0Ahttp://dx.doi.org/10.1 038/nature21059\%0Ahttp://journal.sta inkudus.ac.id/index.php/equilibrium/ar ticle/view/1268/1127\%0Ahttp://dx.doi .org/10.1038/nrmicro2577\%0Ahttp://

Kamus Besar Bahasa Indonesia (2020:791). Devinisi Peladang

Mali, Y. A., Uskono, N., \& Taus, W. (2019). Koordinasi Pemerintah Desa Dalam Penyusunan Rencana Kerja Pemerintah Desa (RKPDes) (Penelitian di Desa Manumutin Silole Kecamatan Sasitamean. JIANE: Jurnal Ilmu Administrasi Negara, 1(April), 56-72.

Nyak Fadhlullah SHI. (2017). Kajian Kriminologi Terhadap Penanam Ganja (Studi Kasus di Kecamatan Beutong Ateuh Banggalang Kabupaten Nagan Raya). Legitimasi, Vol. VI No. 1, Januari-Juni 2017, VI(1), 89-113

Sugihartatmo. (2015). koordinasipengelolaan-program-jaminan-sosial. Jakarta: Lpm Universitas Pasundan

Pasolong, H. (2010). teori Administrasi Negara. Bandung: Alfabeta.

Suharyadi, H., \& Insani, M. A. (2016). 
Manajemen Pemerintahan Dalam Program Unit Reaksi Cepat Tambal Jalan Di Kota Bandung Tahun 2015. CosmoGov, 2(2), 239. https://doi.org/10.24198/cosmogov.v2i 2.10014

Suyedi, S. S., \& Idrus, Y. (2019). Hambatan-Hambatan Belajar Yang Mempengaruhi Hasil Belajar Mahasiswa Dalam Pembelajaran Mata Kuliah Dasar Desain Jurusan Ikk Fpp Unp. Gorga: Jurnal Seni Rupa, 8(1), 120.

https://doi.org/10.24114/gr.v8i1.12878 Helviza, I., Mukmin, Z., \& Amirullah. (2016). Kendala-Kendala Badan Narkotika Nasional (Bnn) Dalam Penanggulangan Penyalahgunaan Narkotika Di Kota Banda Aceh. Jurnal Ilmiah Mahasiswa Pendidikan Kewarganegaraan Unsyiah, 1(1), 128146.

Taliziduhu, N. (1997). Ilmu Pemerintahan (Kybernologi). Jakarta: Rineka Cipta.

Wikipedia. Peladangan. https://id.wikipedia.org/wiki/Peladang an 